\title{
The Importance of Comparative Law with Reference to Private International Law
}

\author{
Dennis Solomon* \\ University of Passau \\ 41 Innstrasse, Passau, 94032, Germany
}

Received 18.05.2017, received in revised form 09.06.2017, accepted 24.06.2017

\begin{abstract}
Despite often being decried as overly academic, comparative law is central to the entirely practical question of how to appropriately perform the private international law characterisation of foreign legal institutions. Whilst the traditional focus of both private international law and comparative law has been on state legal systems, this limitation appears increasingly narrow in a globalised world. Private international law could and should also consider the incorporation of the myriad normative orders of transnational and non-state (i.e. religious, social, organisational etc.) origin that dictate the laws of human coexistence. In tackling this, the onus would be on the field of comparative law to ensure an appropriate incorporation of non-state law based on a comprehensive understanding of each non-state norm's original regulatory context.
\end{abstract}

Keywords: conflict of laws, private international law, characterisation, morning gift, non-state law, globalisation, choice of law, lex mercatoria, comparative law, comparative legal methods.

DOI: 10.17516/1997-1370-0085.

Research area: law.

The topic of this paper $^{1}$ - the importance of comparative law with reference to private international law - can look back upon a distinguished academic tradition.. The great Franz $\mathrm{Kahn},{ }^{2}$ an important figure in the development of private international law, who unfortunately died young, gave a report on this very topic at the notable first International Congress for Comparative Law in Paris in the year 1900. ${ }^{3}$

At the same time, Kahn touched upon one of the "eternal questions" raised with regard to the discipline of comparative law, namely its practical relevance, or rather its perceived lack thereof. Comparative law continues to be decried as "too academic", as lacking practical relevance for solving actual legal problems on the basis of specific legal systems. ${ }^{4}$ We shall be coming back to this accusation later and consider at the very least a possible outlook on practical relevance.

Private international law itself does not exactly enjoy the best reputation as a legal discipline either: According to a widely quoted saying, it is a "dismal swamp", in which "learned but eccentric professors [...] theorize about mysterious matters in a strange and incomprehensible jargon". ${ }^{5}$ But at least the aim of private international law is to answer a concrete question of law, namely which law is to be applied

(c) Siberian Federal University. All rights reserved

* Corresponding author E-mail address: dennis.solomon@Uni-Passau.de 
to a case with relevant connections to different states. This is a question of great practical relevance, one where comparative law can provide important assistance, especially when dealing with unfamiliar foreign legal institutions.

The textbook example is the "morning gift" (dower) or mahr of Islamic law: on the occasion of their marriage, the groom promises his bride a certain payment or benefit, whose presentation is usually deferred to the time of the dissolution of the marriage, be it by divorce or death. ${ }^{6}$ For instance, a much-regarded decision of the German Federal Court of Justice from the year $2009^{7}$ concerned a Qu'ran, a mirror, a pair of candlesticks and 15.000.000 Rial. Such agreements are typically found in cases with connections to foreign countries: the spouses might be citizens or residents of a Muslim state, or they might have married there. The case decided by the Federal Court of Justice concerned a marriage in Tehran between two Iranian citizens, who emigrated to Germany shortly after their nuptials and gained German citizenship.

Now, in Germany, as in other countries, different conflict-of-law rules apply to different areas of law. To put it simply, the dissolution of a marriage by way of divorce (as well as some of its consequences) is subject to the law of the spouses' common habitual residence at the time of commencement of divorce proceedings, ${ }^{8}$ maintenance depends on their current habitual residence, ${ }^{9}$ the applicable matrimonial property regime is determined by their shared nationality at the time of marriage, ${ }^{10}$ whilst the general effects of marriage, finally, depend on their current shared nationality. ${ }^{11}$

How is the mahr to be classified within this system? This question cannot be decided solely by looking at its classification within the foreign legal system. The foreign law may have systematic categories that differ greatly from ours - consequently, they may not necessarily fit our own conflict-of-law rules. On the other hand, it does not help to ask how we would regulate the mahr if we introduced it into German law. This would disregard the actual regulatory context of the foreign legal institution.

On the contrary, one must regard the legal, social and economic function of the mahr in the relevant foreign legal order, or, rather, its function within the relevant community: is it its function to ensure the wife receives maintenance? Is it a lump-sum share in the husband's fortune? One of the general effects of marriage perhaps? Or is it meant to protect the wife against improper or abusive repudiation by the husband?

This question can only be decided on the basis of closer knowledge of the legal, social, cultural and religious contexts of the foreign legal institution, and thus only with the means of comparative law. ${ }^{12}$ This was one of the concerns central to Kahn in his report: establishing the fundamentals of a rational, convincing classification of legal institutions into the categories of private international law. ${ }^{13}$

In private international law, this process is called "characterisation". ${ }^{14}$ Today, it is generally accepted that characterisation can neither be performed solely on the basis of our own systematic concepts, nor on the basis of the relevant foreign law. Rather, we must characterise based on an evaluative approach. Even if the conceptually restricted "comparative" approach to characterisation, which one associates with Ernst Rabel ${ }^{15}$, has few followers nowadays, this insight remains valid.

For nowadays we practise "autonomous", "functional" characterisation, independent of the substantive categories of individual legal orders, a method of characterisation which analyses the "function" of a legal institute within the framework of a normative order. ${ }^{16}$ In light of this, comparative legal methods are obviously of paramount importance. Thus, private 
international law and comparative law meet at a conceptual level: "functional comparative law"17 finds its PIL counterpart in "functional characterisation". And in both disciplines, the concept of "functionality" leaves ample room for interpretation of both the concept itself and its associated methodology ${ }^{18}$ - which is both a curse and a blessing.

The importance of comparative law for characterisation in private international law is, of course, old hat: we have been aware of it since at least 1900, when Kahn gave it particular emphasis, at the same time establishing characterisation as a structural element of private international law. I would like to place my emphasis today on another, more fundamental question, a question with which private international law continues to grapple, and one where comparative law can perhaps - offer valuable assistance.

Both comparative law and private international law traditionally concern themselves chiefly with national legal systems. There are several reasons for this, which we cannot now pursue in detail. An important factor is certainly the importance of the nation state for the development of modern legal systems, though this statement alone implies a very Europeancolonialist perspective. ${ }^{19}$

The importance of the nation state for the development of legal orders went hand-inhand with a primary focus on national law when engaging with other legal systems. If the state, in the context of private international law, considered the application of other normative orders, then only of such normative orders which were themselves of state origin. One can consider this limitation of scope to state legal orders a mechanism of self-affirmation and self-assurance of the deciding state. ${ }^{20}$

In modern times, however, this restriction to national (or state) legal orders has become more and more questionable. It is increasingly emphasised that private parties are not exclusively subject to state rules, or that, in other words, private parties do not consider only state rules as binding. ${ }^{21}$ Traditional comparative law has many examples of this: tribal law, for instance, might apply to nonstate entities within states. ${ }^{22}$ However, the most notable and important normative orders that run parallel to state law are still religions and their associated behavioural norms. ${ }^{23}$

In our time, however, it is the much-evoked phenomenon of "globalisation" that provides impetus for engagement with non-state law. ${ }^{24}$ What is meant by globalisation is, of course, not always clear. For our purposes, globalisation means an increasing international interconnectedness and interdependence of social, commercial or political life: through the acceleration of transport and channels of communication (particularly through the internet), but also through the concentration of private economic power in multinational organisations, private parties now have the freedom to potentially act worldwide. ${ }^{25}$ This development seems difficult to reconcile with a general subjection of private cross-border relationships to national legal orders.

Running parallel to this observation is the development of the doctrine of autonomous meaning non-state - international commercial law, the so-called "new" lex mercatoria. ${ }^{26}$ The starting point of this doctrine was the observation that the rules of national legal orders are not adequately well adapted to the needs of international commerce. According to the doctrine's proponents, the "international community of merchants" has, over time, developed autonomous rules which are better adapted to its needs, these rules being considered binding by this community, and enforced chiefly by means of arbitration. ${ }^{27}$

The doctrine of "lex mercatoria" has been the subject of fierce debate for half a century. It is not only the existence of a sufficiently 
homogenous "international community of merchants" and of the opinio juris necessary for the formation of customary law that are in doubt, but also the existence of sufficiently concrete legal principles. ${ }^{28}$

However, this has not prevented the European legislator from attempting to legitimise such non-state rules as valid choices of law for contracts. The original draft of the Rome I Regulation on the law applicable to contractual obligations contained the following clause:

"The parties may also choose as the applicable law the principles and rules of the substantive law of contract recognised internationally or in the Community." 29

In the end, as a result of reservations expressed in trade and commerce, this clause was not included in the regulation. ${ }^{30}$ The current law therefore only allows for a choice of state law as lex contractus. Yet the doctrine of lex mercatoria remains a desideratum for at least some commentators. ${ }^{31}$

For the proponents of this doctrine, comparative law is naturally of great importance. As a hypothetical customary international commercial law is not written down anywhere, its rules would have to be drawn from a comparative analysis of other legal regimes, meaning primarily transnational sources of law, namely international agreements such as the CISG, model laws, standardised contractual terms, trade customs and the decisions of international arbitral tribunals. ${ }^{32}$ The development of general legal principles from such transnational sources is of course a task for the field of comparative law.

Remarkably, it was later widely suggested to draw the contents of the "lex mercatoria" primarily from two legal regimes (both devised on an international level by committees of experts), namely the "Unidroit Principles of International Commercial Contracts" 33 and the "Principles of European Contract Law" developed by the so- called Lando Commission. ${ }^{34}$ For these rules were developed largely through a comparative analysis of positive law: while a particular focus was on the international UN Sales Law, national legal solutions also played a significant role.

It is, however, not only the doctrine of lex mercatoria that has gained new impetus through globalisation: the kinds of circumstances in which one might consider the application of nonstate law have also expanded considerably. If one understands globalisation in a broad sense - as an increasing international interconnectedness of living conditions in general-then the phenomenon is of course not limited to the narrow scope of international commerce. Indeed, globalisation in this sense may include, in principle, private, family or religious relationships.

In light of this development, there have been attempts from the perspective of legal pluralism to draw conclusions from globalisation for private international law. Legal pluralism is the phenomenon that social behaviour is determined by the legal norms of different, coexisting normative systems, state law being just one of several. ${ }^{35}$ In addition to state law, there are other normative orders which fulfil legal functions in their own areas - which primarily means that they regulate and control social behaviour - be it the normative order within a family or that among the "international community of merchants".

So, in addition to the state, there are other actors, organisations or communities which independently of the state - lay down their own non-state rules that, within their particular scope, claim validity and are linked to special types of sanctions, making them "laws" in a functional sense. ${ }^{36}$

The more or less clearly expressed implication for private international law is this: if these normative orders are law, then the state must - or, at least: should - recognise them and, in principle, enforce their rules. 
This is not the place to expand upon the consequences this has for the theory of private international law. Traditional conflict-of-laws rules would require fundamental reforms and would need to be supplemented by a system of functional assignment - meaning assignment either to the state or non-state sphere - a system of assignment that presently can be conjectured only rudimentarily, and whose development would doubtlessly occupy several generations of conflict-of-laws scholars. ${ }^{37}$

Much more important for our topic is the recognition that this task, too, could not be convincingly tackled without profound comparative legal research. Comparative law would insofar have to open itself to non-state normative orders on two levels, which can be well illustrated by regarding religious norms:

On one level, it is a question of considering the relevant regulatory content of the norm as well as its methodological, social, cultural and religious regulatory context: ${ }^{38}$ it is not only the superficial content of the norm, be it the canonical prohibition of divorce or the Islamic repudiation or mahr, that must be considered. It is crucial to develop an understanding of the normative basis of validity and the associated methodological guidelines for the application and further development of the relevant norm, and to develop an understanding of the sanctions that may be linked to a violation of a religious behavioural norm. For example, the religion itself may not demand earthly sanctions for the violation of a particular rule. ${ }^{39}$ Such rules regarding consequences that are inherent to a normative system cannot be ignored in an "external" application of such norms.

On a different level, it is important to identify the various ways in which a state legal order can "process" or "incorporate" such nonstate normative systems. Particularly the states belonging to the Islamic legal sphere have come up with a wide range of mechanisms for the incorporation of Islamic religious law - ranging from a broad and direct implementation in Saudi Arabia to Islamic-inspired national legal codes with a varying strictness of adherence to the underlying religious teachings. ${ }^{40}$ Other states, such as Israel, are, at least in certain areas, less willing to impose state rules, and generally leave questions of family and religious law to the respective religious communities (and their jurisdictions). ${ }^{41}$

These regulatory concepts must be considered when answering the question of how national conflict-of-laws rules - i.e. private international law - should deal with non-state normative orders. Precisely because this is a matter of non-state legal orders, their relevance is not dependent on the presence of a foreign connection: in the case decided by the Federal Court of Justice, ${ }^{42}$ the bride and groom could conceivably have agreed a mahr encompassing a Qu'ran, a mirror, a pair of candlesticks and, perhaps, 1500 EUR after acquiring German citizenship. Although there would not have been a problem of conflict-of-laws characterisation, this would have raised an issue of substantive law, as German family law has strict requirements for agreements on matrimonial property and maintenance. ${ }^{43}$ At the very least in this respect it is once again important to gain an understanding of the mahr's functional purpose.

A pluralistic legal world needs comparative law. We need it to, with sense and reason, do justice to the various normative conditions of our coexistence. This is undoubtedly elementary, practical use of comparative law.

But, at least at the end of these considerations, allow me to take a somewhat less utilitarian perspective: for in any case comparative law enhances our understanding of the very subject of our discipline: the law. In other words, it enriches us. And that, I think, is something we can be very satisfied with. 
This paper was presented (in the German and the Russian languages) at the Symposium on Comparative Law, held at the Faculty of Law of the Siberian Federal University, Krasnoyarsk, on September 22, 2016. The text retains its original format as a lecture; footnotes have been added, but no claim is made to their completeness. My thanks go to Manuel Gruber for providing the English translation.

2 Kegel, Schurig. (2004). Internationales Privatrecht, 9th ed., Munich, 186 et seq.; Lamberg. (1975). Die kollisionsrechtliche Lehre von Franz Kahn (1861-1904), Diss.,Göttingen, (with a biographical introduction XXI-XXXVI); Weber. (1986). Die Theorie der Qualifikation. Franz Kahn, Etienne Bartin und die Entwicklung ihrer Lehre bis zur universalen Anerkennung der Qualifikation als allgemeines Problem des Internationalen Privatrechts (1890-1945), Tübingen, (with a short biography of Kahn, 14-23). The collected writings of Franz Kahn were published by Lenel, Lewald(eds.), (1928). Abhandlungen zum internationalen Privatrecht (2 Vols.), Munich, Leipzig.

3 Kahn, Bedeutung der Rechtsvergleichung mit Bezug auf das Internationale Privatrecht, in Abhandlungen zum Internationalen Privatrecht (supra n. 1), 491 et seq.; regarding the relevance of comparative law to private international law, also see Rühl. (2016). Rechtsvergleichung und europäisches Kollisionsrecht: Die vergessene Dimension, in Zimmermann (ed.), Zukunftsperspektiven der Rechtsvergleichung, Tübingen 103 et seq., 108 et seq.; Zweigert, Kötz. (1996). An introduction to comparative law, 3rd ed., Tübingen, 6.

4 Kischel. (2015). Rechtsvergleichung, Munich, $\$ 2$ nos. 1 et seq.

5 Prosser. (1953). Interstate Publication, In Michigan Law Review, 51, 959, 971.

$6 \quad$ Kischel (supra n. 3). § 10 no. 84; Rohe, (2009). Das islamische Recht, Munich, 85 et seq.

7 BGH (9.12.2009, XII ZR 107/08), Juristenzeitung 2010, 733, note Wurmnest = Praxis des Internationalen Privat- und Verfahrensrechts, 2011, 85, note Yassari 63.

8 Council Regulation (EU) No. 1259/2010 of 20 December 2010 implementing enhanced cooperation in the area of the law applicable to divorce and legal separation (O.J. L 343, p. 10), Art. 8.

9 Council Regulation (EC) No. 4/2009 of 18 December 2008 on jurisdiction, applicable law, recognition and enforcement of decisions an d cooperation in matters relating to maintenance obligations (O.J. L 7, p. 1), Art. 15; Protocol of 23 November 2007 on the Law Applicable to Maintenance Obligations (O.J. L 331, p. 19), Art. 3.

10 Einführungsgesetz zum Bürgerlichen Gesetzbuch (Introductory Act to the German Civil Code), Art. 15 (1), 14 (1).

11 Einführungsgesetz zum Bürgerlichen Gesetzbuch, Art. 14 (1).

12 Kegel, Schurig (supra n. 1), 343 et seq.; von Bar, Mankowski. (2003). Internationales Privatrecht, Vol. 1, 2nd ed., Munich, $\S 7$ nos., 161 et seq.; Rabel, Conflict of Laws, Vol. 1, 2nd ed., Michigan 1945, p. 403.

13 Kahn (supra n. 2), p. 492.

14 Kegel, Schurig (supra n. 1), pp. 325 et seq.; von Bar, Mankowski (supra n. 11), § 7.

15 Rabel. (1931). Rabels Zeitschrift für ausländisches und internationales Privatrecht, 5, 241 et seq.

16 Kegel, Schurig (supra n. 1), 346 et seq., von Bar, Mankowski (supra n. 11), § 7 nos. 173 et seq.

17 For this method see, in particular, Zweigert, Kötz (supra n. 2), 34 et seq.; cf. Kischel (supra n. 3), § 1 nos. 14 et seq., § 3 no. 3.

18 For a recent critique of the method of "functional" comparison, see Kischel (supra n. 3) § 3 nos. 6 et seq.

19 Also see, for example, Michaels, Jansen, (2008). Europeanization, Globalization, Privatization, in Jansen, Michaels (eds.), Beyond the State - Rethinking Private Law, Tübingen, 83 et seq.

20 Also see Michaels, Jansen. (2008). Private Law and the State - Comparative Perceptions and Historical Observations, in Jansen, Michaels (eds.), Beyond the State - Rethinking Private Law, Tübingen, 46 et seq.

${ }^{21}$ Also see Zumbansen. (2012). Defining the Space of Transnational Law: Legal Theory, Global Governance, and Legal Pluralism, in Transnational Law and Contemporary Problems, 21.2, 305 et seq.; Michaels. (2009). Global Legal Pluralism, Annual Review of Law \& Social Science, 5, 243 et seq.

22 Kischel (supra n. 3), § 8 nos. 24 et seq.

23 Kischel (supra n. 3), § 10 nos. 1 et seq.,nos. 157 et seq.,nos. 179 et seq.

24 See, for example, Zumbansen. (2012). Politische Ambivalenzen privater Normsetzung in der Globalisierung, in Keller, Wiprächtiger (eds.), Recht zwischen Dogmatik und Theorie: Marc Amstutz zum 50. Geburtstag, Zürich, 395 et seq.; Shaffer, Pollack. (2010). Hard vs. Soft Law: Alternatives, Complements and Antagonists in International Governance, Minnesota Law Review, 94, 706 et seq.

25 Cf. Michaels, (2005). Welche Globalisierung für das Recht? Welches Recht für die Globalisierung? Rabels Zeitschrift für ausländisches und internationales Privatrecht, 69, 526 et seq.

26 See, for example, Dasser. (1998). The "new" law merchant and the "old" - Sources, content, and legitimacy, in Carbonneau (ed.), Lex mercatoria and arbitration - A discussion of the new law merchant, California, 53 et seq.; Schmidt. (2007). Lex mercatoria - Allheilmittel? Rätsel? Chimäre?, in Murakami, Marutschke, Riesenhuber (eds.), Globalisierung und Recht - Beiträge Japans und Deutschlands zu einer internationalen Rechtsordnung im 21. Jahrhundert, Berlin, 162 et seq.; Michaels. (2007). The True Lex Mercatoria. Private Law Beyond the State, Indiana Journal of Global Legal Studies, 14, 447 et seq.; Kischel (supra n. 3), § 11 nos. 48 et seq.

27 See, in particular, Goldmann. (1964). Frontières du droit et "lex mercatoria", Archives de philosophie du droit 9, 177 et seq.; also see Baron. (1999). Do the Unidroit Principles of International Commercial Contracts form a new lex mercatoria? Arbitration International, 15, 116 et seq.; Horn. (2009). Transnationales Handelsrecht - Zur Normqualität der lex mercatoria, in Bitter, Lutter, Priester, Schön, Ulmer (eds.), Festschrift für Karsten Schmidt zum 70. Geburtstag, Köln, 709 et seq.

28 For a particularly sharp criticism see von Bar, Mankowski (supra n. 11), $\$ 2$ nos. 75 et seq. ("Die Lehre von 'der' lex Mercatoria hält in keinem der von ihr für sich reklamierten Punkte näherer Kritik stand. Sie ist rechtsquellentheoretisch falsch, begrifflich verschwommen und rechtspolitisch verfehlt").

29 Commission of the European Communities, Proposal for a Regulation of the European Parliament and the Council on the law applicable to contractual obligations (Rome I), COM. (2005). 650 final (December 2005), p. 15, Art. 3(II). 
Schinkels. (2007). Die (Un) Zulässigkeit einer kollisionsrechtlichen Wahl der UNIDROIT Principles nach Rom I. In Wirklich nur eine Frage der Rechtspolitik? Zeitschrift für das Privatrecht der Europäischen Union, 110.

32 Kischel (supra n. 11), § 11 nos. 55 et seq.; Berger. (1999). The creeping codification of the lex mercatoria, Den Haag, London, Boston, 44 et seq.

33 Unidroit Principles of International Commercial Contracts (PICC). (2010). 3rd ed.

34 Lando, Beale. (1999). Principles of European Contract Law, Parts I and II, prepared by the Commission on European Contract Law, Den Haag; Lando, Clive, Prüm, Zimmermann. (2003). Principles of European Contract Law, Part III, prepared by the Commission on European Contract Law, Den Haag.

35 See, for example, Teubner. (1997). Global Bukowina: Legal Pluralism in the World Society, in Teubner (ed.), Global Law without a State, Aldershot, 3 et seq.; Michaels (supra n. 20), 243 et seq.

36 Michaels (supra n. 20), 258 et seq.

37 Cf. Michaels (supra n. 24), 536 et seq.

38 Regarding the "contextual" method of comparative law, see Kischel (supra n. 3), § 3 nos. 146 et seq.

39 Kischel (supra n. 3), § 10 nos. 74 et seq.; Rohe (supra n. 5), 8 et seq.

$40 \quad$ Kischel (supra n. 3), § 10 Rn. 127 et seq.

41 Kischel (supra n. 3), § 10 nos. 175 et seq.

42 Supra, n. 6.

43 Cf. $\S 1410$ and $\S 1585$ c s. 2 of the German Civil Code (BGB); in that respect, also see Yassari (supra n. 6), 67 et seq.

\title{
О значении сравнительного правоведения
}

в связи с международным частным правом

\author{
Д. Соломон \\ Университет Пассау \\ Германия, 94032, Пассау, Иннштрассе, 41
}

Несмотря на частое осуждение за чрезмерную академичность сравнительное правоведение имеет большое значение для практического вопроса о том, как надлежащим образом квалифицировать инностранные юридические институты в международном частном праве. Хотя традиционно международное частное право и сравнительное правоведение изучают государственные правовые системы, это ограничение сферы исследования представляется слишком узким для глобализованного мира. Частное международное право может и должно также учитывать множество норм межнационального и негосударственного характера (религиозныхx, социальных, организационных и т.д.), которые диктуют правила сосуществования человека. В решении этой проблемы именно сравнительное правоведение должно обеспечить надлежащее внедрение этих норм, основанное на комплексном понимании первоначального нормативного контекста каждой из негосударственных норм.

Ключевые слова: коллизионное право, международное частное право, квалификация, подарок мужа жене на свадьбу, негосударственная норма, глобализация, lex mercatoria, сравнительное правоведение, методы сравнительного правоведения.

Научная специальность: 12.00.00 - юридические науки. 